\title{
From Dan To Danita: LGBT Based Discrimination And Issues Of Religious Freedom
}

\author{
C. Kenneth Meyer, Drake University, USA \\ Kory Schnoor, Drake University, USA
}

\begin{abstract}
In this two-part case study, Dan Flint faced a dilemma that was not of his own making. He saw himself as a "...female imprisoned in a male's body." In attempting to get a "grip" on his gender identity, he consults a renowned sex therapist and a barrage of emotions and feelings that make up his inner core nature are revealed. He faces the reality that "coming-out" is fraught with many issues and dilemmas. Will his transgendered state be understood? Will he undergo surgical procedures which will give him female anatomical parts? How will he face his work environment, supervisors, and co-workers? And finally, will he be accepted as a person with value and dignity? The case shows the difficulties that Dan faced in transitioning to Danita in a workforce that reacted with confusion, uncertainty and skepticism. The case presents in the first part, seven questions that bring up the interpersonal, ethical and managerial questions imbedded in the case study, and explore how a supervisor might prepare the organization for dramatic change. In the second part, President Obama's Executive Order on prohibition of discrimination on LGBT workers, coupled with Employment Non-Discrimination Employment Act (ENDA), and the Supreme Court decision on religious freedom (Hobby Lobby) are woven into a series of important issues, concluding with a debate scenario.
\end{abstract}

Keywords: LGBT, Transgendered; Sexual Harassment; Gender Identify; Sex Discrimination; Sexual Orientation; Civil Rights Act of 1964; Change and Communication; Religious Freedom; Executive Orders; Employment NonDiscrimination Employment Act (SNDA)

Applicable Courses: Human Resource Management, Public and Nonprofit Personnel Administration, Diversity in the Workplace, Changing Workplace, and Ethics and Management

\section{INTRODUCTION; AWARENESS, DENIAL, AND REALITY}

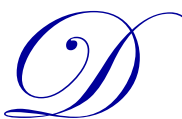

aniel Flint knew he was not alone in facing the trials and tribulations that he would endure as a transgendered person. He had been active in the GLBT (Gay, Lesbian, Bisexual, and Transgendered) movement in town, but he kept his own sexual identify as a deeply held secret. He had sought counseling before, but he was reluctant then to share his true feelings with his counselor. Over time, his level of courage grew and now he wanted the "tug-of-war" in his life to be resolved. He was terribly conflicted and he would often whisper to himself in a state of desperation, fear, guilt, and heighten anxiety, "I am a female imprisoned in a male's body—-so, how do you like me now."

Today, he would have his fifteenth session with Dr. Joyce Reynolds. Similar to all of the previous sessions, it began with the customary friendly exchanges, the obligatory updates of the activities during the week, and, of course, the progress he had made in transforming himself from a man to a woman.

Dan began seeing Dr. Reynolds, a renowned sex therapist, six months ago, so he could discuss his knowing, lifelong feelings that he felt alien to his own body. He told Dr. Reynolds that since "...the age of ten, or 
there about, I thought that I would rather die than to live the rest of my life as a man. My emotions, feelings—my inner core nature - is more female directed and oriented than male."

Dr. Joyce Reynolds was one of the most experienced therapists in sexual reassignment in the state and had heard, over the years, the same kind of story from some of her other clients. She always listened attentively and with empathy to what Dan told her and as they went through session after session, Dan developed a comfortable and trusting relationship with her; after all, many of his questioning support group had recommended her because of her empathy and stellar level of professionalism. However, this visit would be more difficult than the others for they had decided it was time for Dan to begin informing important people in his life of his decision to become "Danita."

Dr. Reynolds advised Dan saying, "With only two months to go before your surgery, you must begin to introduce your new self to your co-workers; even before they see you as woman." They talked about how hard it would be to talk about this with those at work, but Dan generally believed that most of his associates would eventually understand. Dan had already crossed one major hurdle when he told family members and his close friends and was gratified that they had noticed the gradual transition taking place in his life and embraced his personal decision. However, Dan knew it would be especially difficult to talk about his transition and impending sex change with his coworkers who might not embrace his decision with same empathy, caring concern, and magnanimity. On a personal side, would he make a radical change to his present name? Perhaps, he would take on a new name, such as Joyce, Alicia, Paris or even a more exotic sounding international name like London? But he had reached the decision long ago and his new name would be a form of Dan — that of Danita—and, at least for now, that suited him perfectly well.

\section{Employment, Interpersonal Dynamics, and Protracted Therapy}

Dan had become a permanent employee of the State Department of Transportation, and as an inspector, he interacted on a daily basis with a wide range of professional, technical, clerical and manual employees. In brief, he dealt with contractors, vendors, field staff and upper management across the five state transportation districts. He understood in his own mind, that many of his associates that he worked with and befriended over the years, would have a difficult time acknowledging, not to mention, accepting or endorsing his sex reassignment decision.

As Dan and Dr. Joyce continued the therapy, he told her that he worried about those colleagues who would not accept his sex change and would, he feared, be duplicitous and ridicule and make fun of him. Indeed, he stated, "I am prepared to accept their confusion, but not their discrimination or condemnation." Nevertheless, the session had drawn to a close and an agreement had been reached that Dan would begin informing his co-workers about the upcoming surgery. "Chances are," Dan said, "they've already noticed my hair getting longer and some of the other physical changes brought on by the hormones."

\section{TRANSGENDERED IN THE WORKPLACE—IMPLICATIONS AND REPERCUSSIONS?}

The new work week began in typical fashion with Dan's co-workers shuffling into the office at 8 o'clock, fully charged from their weekends that were filled with sundry events and some rather uneventful occurrences that begged for a receptive ear. They were preparing themselves to face the rest of the work week that lay ahead and "getting back into the routine and mundane swing-of things." Dan had dreaded this day for months and as he closed the car door of his 'lentil' green Focus, twinges of anxiety and unfocused fear and uncertainty pulsed though the corridors of his "secret" mind. Certainly, for Dan, at least, this would be an eventful day for him, if not also for his co-workers. After all, it was the day that Dan finally came out and announced his true gender identity.

Dan walked purposefully and directly to his gray-steel "government issued" desk and settled in to do his routine duties. Around mid-morning, Dan approached Rose Bailey, his immediate supervisor, and asked if he could have a "confidential and closed-door meeting"- something he had never asked for in his many years of service. Rose was known not only as a competent manager, but also as a supportive, trustworthy, and "people-centered" supervisor with over twenty-years of service to the state tucked under her administrative belt. Dan felt the twin emotions of "tension and relaxation" cascade over his body as he walked into Rose's office. Dan respected and admired Rose and often spoke of her caring concern, compassion and probity in his counseling sessions with Dr. Reynolds. 
Looking directly into Rose's eyes, Dan began to speak to Rose in a voice filled with vacillations. He said, "Rose, there is something that I must tell you and ask that you try your best to understand the personal decision I have made. You may have noticed that my hair has grown out and that I am undergoing some small, but noticeable physical as well as body language changes. Well, I have been taking female hormones in preparation for a surgery I will be having in a couple of months."

Rose began to minimally understand the physical implications and alterations that were probably involved, although she had no clue as to the full range of socio-psychological and sexual changes Dan had already addressed in his life. Looking confused, but lending an attentive ear, Rose said: "Dan, I'm not exactly sure what you're trying to tell me here". Dan responded with a manner of quietude: "Rose, I'm having sexual reassignment surgery to change myself from a man to a woman. When the surgery is completed I will have changed from being Dan to Danita." Rose's reaction was one of exaggerated surprise, confusion, but also inquisitiveness, at what she had just been told.

Dan further explained, "Rose, I've spent nearly all my life fighting the fact that I was born in the wrong body. It's caused me to feel depressed for many years. I feel like I'm hiding who I truly am - and I hate my body. This is not something that I have willfully chosen-it seems normal to me when I let my inner female-self emerge." Rose admitted to Dan that she was taken aback by his revelation, but that she would be supportive of his decision as best as she could - for they, too, were not only colleagues, but friends. Then she asked Dan to wait on telling anyone else in the department until she had a chance to talk with Henry Rowe, the department's human resource manager. Dan was reluctant to have Rowe informed for fear that he may not understand, yet he reluctantly agreed to go along with Rose's position.

\section{Supervisors Deal with a Transgendered Workforce}

Events began to change rapidly and later that day, Rose called Dan and asked him to come to her office. "Dan, I just finished talking to Henry about your situation," Rose began. "Of course, he's a professional and will keep this situation confidential from other employees. However, he wants to talk this decision you have reached through with you. As difficult as this is, he's concerned that some in the department may have a difficult time adjusting to the news." Rose seemed uncomfortable with the tenor and words of the conversation, and said: "Frankly, Dan, he thinks that if you tell some of the field staff, they may refuse to work with you. I'm very sorry to tell you this. You know how prejudicial and discriminating people can be!"

Dan felt like he had just received a blow to his stomach and that the wind had been knocked out of him. "I'm not exactly sure how to react to this Rose," he retorted. "This is my decision and it affects my life and happiness." Then, Dan grew angry as he continued, "I can't help it if some closed-minded people won't accept who I am. Shouldn't the department treat me the same way it treats everyone else? Don't I deserve to be who I am without fearing the scourge of discrimination?"

Rose feared that she had approached Dan the wrong way and communicated the wrong sentiments about his sex change and, perhaps, had not given full throttle to the message she reported from Rowe. She felt awful. "Dan, I understand and don't want you to think that we're not supportive of you. It's just that, well, we must consider the impact on all employees your decision will have on the department. I believe Henry's concern is valid. I mean, you know that some of the staff may have a hard time with this. They are used to you as Dan. Some may not understand this need that you feel to have your true identify realized. Hell, they might wonder which restroom you'll use - the men's or women's or the unisex restroom. And with your new name of Danita, they may refuse to call you anything other than Dan."

The conversation between Dan and Rose lasted only a few minutes, but both left work with a mutual feeling of disappointment and uncertainty of what steps should now be taken. Dan had made a commitment to himself after a lengthy discussion with Dr. Reynolds, that he would begin informing his co-workers about his decision. He went home that night and thought about the years of progress he had made in his job; the effort he had put forth to advance the mission of the department; and the respect he had developed for those he worked with over the years. Was all of this work history now for naught, for his gender status would become front and center and laid on the line tomorrow. 


\section{DAN ADDRESSES HIS COLLEAGUES AND ASKS TO BE TREATED WITH RESPECT, DIGNITY, AND EQUALITY"}

Tomorrow arrived and Henry, Rose and Dan met to discuss his "coming out" to his associates. Henry began, "Dan, I know this has been difficult for you and I can't imagine what you're going through. To be honest, I'm not sure I totally understand, but it's my role to make sure you find your work environment to be comfortable, safe, secure and non-threatening. I fear, having said all of this, that there are others in the department who may react to your revelation not only with confusion and disbelief, but will be uncomfortable having interactions with you in the future." He continued, "As you know, it is my duty to keep your and their concerns in mind. This situation isn't just about you!"

Dan was unsure of what Henry just told him, although he seemed to be genuinely supportive. "Thank you for understanding," Dan replied. "Although my decision might well impact others in the department, shouldn't they be expected to treat me just the same way as they treat everyone else? Don't I deserve to be treated with dignity and respect?" he said.

Henry agreed that Dan deserved to be treated fairly and equally. And he further exclaimed, "Under the law, you are protected in your employment. I want to make that crystal clear. Your employment with this department will not be affected in any way by this change. I suggest, however, that we might want to consider the nature of the interactions you might have over the next few months with your co-workers. Dan, you know that many of the field staff can be, well, limited in their understanding of issues like this. During the first few months of your transition, how would you feel about focusing your role and activities at the central office?"

Dan reacted with sadness with what he had just been told. Dan said, "I'm not sure I agree with you, Henry. I think all my co-workers will take some time to adjust, but I have faith that they will eventually come around. I can't hide under my desk here at the central office. I don't think it's fair, but I'll accept your decision." Henry, satisfied that they had reached a level of mutual understanding, ended the conversation by stating, "I'll help in any way I can to make this transition as smooth as possible." And Rose added her own voice of how she too would be of assistance to Dan as the details of his decision became public knowledge.

The meeting with Henry Rowe and Rose Bailey had ended. Dan felt agitated by what had just transpired and asked Rose if he could take the rest of the day off in order to process the events and decisions that had just transpired. He knew full well that his presence in the office would not completely be the same, but he felt he could deal with what faced him now with pride and confidence for he had become his own woman. And, he would begin to inform his colleagues and hope that they would trust that he had made the right decision for himself.

\section{QUESTIONS AND INSTRUCTIONS}

1. What role should Henry Rowe play as Director, Human Resources Department, in dealing with Dan Flint's decision to undergo sexual reassignment? Please explain.

2. As program supervisor, did Rose Bailey demonstrate a concern for Dan Flint's civil rights? Please elaborate. In your opinion, should Dan be protected against the potential discriminatory actions of his coworkers and others he deals with in the course of doing his job and coordinating and inspecting the transportation programs? If yes, why? If not, why not? Please explain.

3. If you were in Henry Rowe's position, how would you have prepared the Department of Transportation for the change that Dan Flint was about to undergo? And, for Rose, what should her role be, if any, in Dan's sexual reassignment decision? What should Rose do to make Dan's transformation to a woman be treated in a non-discriminatory manner?

4. For Dan Flint, how should he "come-out" to his co-workers and others in the Department of Transportation? Please explain.

5. If you were Henry Rowe, how would you go about introducing Danita to her co-workers? Give an example of how you would make this first introduction

6. If you were in Dan Flint's position, would you have accepted the arguments and decisions made by Henry Rowe and Rose Bailey about his work assignment —at least in short-run? Please elaborate. 
7. What, if any, ethical implications are associated with this case study? Please elaborate. What are the moral issues associated with the decision that Danita made? Please explain.

\section{STOP! PLEASE ANSWER QUESTIONS ABOVE BEFORE PROCEEDING TO PART 2 OF THIS CASE STUDY.}

Part2. Please read this Special Announcement before proceeding to the Questions and Instructions portion of this two-part case study.

\section{Bulletin! Breaking News! President Obama Makes Historic Announcement}

As this case study was being researched and written, a major announcement was made by President Barack Obama concerning LGBT and transgendered job discrimination in the United States. The Executive Order was issued to coincide with LGBT Pride Month (June), and prohibits federal contractors and subcontractors from discrimination on the five traditional areas of discrimination (race, color, religion, sex, or national origin) and adds one more protection against discrimination to the existing criteria presented in the Civil Rights Act of 1964—LGBT. The White House stated:

"Today, millions of Americans in most states in the country go to work every day knowing they could lose their jobs simply because of who they are or who they love." Further, "No current federal law adequately protects lesbian, gay, bisexual, and transgender (LGBT) workers from employment discrimination."

Accordingly, with this executive order, federal contractors and subcontractors are prohibited from discriminating in employment areas based on sexual orientation and gender identity--transgendered status (www.huffingtonpost.com/ 2014/06/16/Obama-enda_n_5499377.html). Previously, President Obama issued Executive Order 11478 that dealt with discrimination on the basis of sexual orientation.

\section{President Obama and the Use of Executive Orders}

The President is authorized to set polices governing federal contracting and procurement by the Federal Property and Administrative Services Act of 1949 (FPASA)--a law passed 65 years ago that has been used by presidents, regardless of party identification, since then. Also, executive orders have been regularly used to affect contracts and procurement in the interest of "economy and efficiency" as prescribed by law. Executive Orders have been used to deal with discrimination in social or economic areas, age, and race, color, religion, sex, or national origin, to mention just a few. Thus it is not surprising that President Obama would use this method to address discrimination against those employed with federal contractors and subcontractors on the basis of sexual orientation and gender identity. http://www.brookings.edu/blogs/fixgov/posts/2014/06/19-obama-executive-order-lgbt-federalcontractors-hudak

Most Americans do not realize that in 32 of the 50 states, it is legal to terminate someone merely on the basis of their gender identity and perfectly legal to fire someone in 29 states on their sexual orientation.

\section{Employment Non-Discrimination Act (ENDA): A Dab of History Will Do Ya}

The legislation entitled Employment Non-Discrimination Act (ENDA) has been introduced repeatedly in the U.S. House of Representatives since 1974 and would, if it became law, prohibit work place discrimination in both hiring and employment on the basis of sexual orientation and more recently, gender identity, for employers with at least 15 employees. Although the official statistics on the number of LGBT employees that would be covered in the private sector is unknown if ENDA became law, estimates range from 5-8 percent of the civilian workforce would be affected ( 8 to 12 million or more) and nearly 1.5 million would be affected if they worked directly for government. Other estimates place the number of civilian federal contract workers that would be covered by the E.O. "... as many as 16 million." http://www.huffingtonpost.com/2014/06/16/obamaenda_n_5499377.html 
The level of discrimination reported varies by LGBT status, with transgendered persons reporting higher rates of discrimination, harassment, and mistreatment than their LGB brothers and sisters. In fact, according to the 2008-2009 National Transgender Discrimination Survey, 97 percent of transgendered people have been harassed on the job, 26 percent have been fired because of gender identity and 19 percent have been homeless due to their identity, and the rate of under-employment and unemployment is also much higher among transgendered persons. These numbers stand in stark contrast to the 88 percent of voters surveyed who indicated that elected officials vote on anti-discrimination measure that included sexual orientation and gender identity "... would have no impact on their decision or would make them more likely to vote for that candidate in the future" (Global Strategy Group, GENDA Study, 2208, New York Voters). This study was only generalizable for the State of New York, since it was not a national study. (http://transequality.org/resources/enda by the numbers.pdf Overall, with the executive order on LGBT, it makes it 100 percent clear that federal employees, regardless of orientation or identity, must be treated equally.

In President Obama's concluding remarks on the LGBT announcement he reinforced what Dr. Martin Luther King stated many times during his life: “...injustice anywhere is a threat to justice everywhere." The president went on to say:

"That's how we continue our nation's march towards justice and equality. That's how we build a more perfect union -- a country where no matter what you look like, where you come from, what your last name is, who you love, you've got a chance to make it if you try. You guys have shown what can happen when people of goodwill organize and stand up for what's right. And we've got to make sure that that's not applied just one place, in one circumstance, in one time. That's part of the journey that makes America the greatest country on Earth.”

\section{QUESTIONS AND INSTRUCTIONS:}

8. Please research the EEOC statistics and identify the number and percentage of discrimination complaints that have been filed on the basis of these eight (8) protected classes: sex, race, religion, color, national origin, age, veteran status, and disability. What did you find?

9. Please surf the WEB, especially the National Center for Transgender Equality (www.TransEquality.org) and research the number and different types of mistreatment, harassment and discrimination which people face on the basis of gender identity and how prejudicial and discriminatory behavior affects their work and life chances. Please elaborate.

\section{General Class Discussion: A Debate on the Pros and Cons of E.O. on LGBT and Supreme Court Decision on Religious Freedom in the Hobby Lobby Case}

Instructions: Class participants should be placed into two groups: One group will argue the pros associated with the expansion of Religious Freedom Restoration Act (RFRA) prohibitions against religion based discrimination; and the other group will argue the cons associated with Hobby Lobby decision.

\section{The Issue:}

In political commentaries on anti-discrimination laws, it is commonly stated that the "...arc of history bends towards justice." In your opinion, does this recent E.O. take us further toward justice in the United States, or does it, as some have argued, especially in light of the recent Supreme Court ruling in Burwell v. Hobby Lobby Stores, No. 13-354, and Conestoga Wood Specialties v. Burwell, No. 13-356, 2014, “...that corporations controlled by religious families cannot be required to pay for contraception coverage for their female workers" (http://www.nytimes.com/2014/07/01/us/hobbylobby-case-supreme-court-contraception.html) impinge on the right to" religious liberty" for those whose religious convictions would stand in direct opposition to recent LGBT proclamations that prohibit discrimination on the basis of sexual orientation and gender identity.

Alternatively, as Associate Justice Ruth Bader Ginsburg's in her dissent opined: 
"Would the exemption the Court holds RFRA demands for employers with religiously grounded objections to the use of certain contraceptives extend to employers with religiously grounded objections to blood transfusions (Jehovah's Witnesses); antidepressants (Scientologists); medications derived from pigs, including anesthesia, intravenous fluids, and pills coated with gelatin (certain Muslims, Jews, and Hindus); and vaccinations (Christian Scientists, among others)?"

This recent executive order and Supreme Court decision is embedded in controversy that is steeped in religious, political, and other cultural considerations. For instance, does objection to the violation of religious liberty also extend to minimum wage laws? Or, equal pay for women who perform the same type of work as men? Or to all forms of contraception and myriad of different surgical procedures (cosmetic to life saving), and to other government regulations (plural marriages) that may be deemed "offensive" on the basis of religious faith? Interestingly, on the basis of faith orthodoxy, would individuals or corporations be protected if their decisions ran counter to civil rights protections, fair housing laws, and would they be exempted from obeying equal employment laws and refusing to serve LGBT customers http://patimes.org/problem-hobbylobby-decision-legal-confusion/ Last, what if the Bible or Quran or some other "sacred" religious text forbids co-habitation (before marriage), fornication, or objects to women supervising men - having dominion over - in the workplace, or perhaps requiring that women receive permission from either their father or husband prior to going to work, etc., should an organization be able to discriminate in hiring and other employment decisions based on these religious beliefs? (Jim Spencer, "Birth control set to grow," Star-Tribune, 7/6/2014, p. A5).

Please explain and support with authoritative sources as you engage in a civil discussion with one another.

\section{AUTHOR INFORMATION}

C. Kenneth Meyer is Thomas F. Sheehan Distinguished Professor of Public Administration, Drake University. He previously held teaching positions at Winona State University, State University of New York, University of South Dakota and the University of Oklahoma, Norman, Oklahoma. He has nearly 300 published case studies that appear in numerous venues. His latest books are entitled: Managing People as Assets; Human Relations in Action; Managing America's Organizations; and Managing Public Service Organizations; Conducting the People's Business; Organizational Change; and..Nonprofit Management and Leadership Case Studies (2014).[Corresponding author Kenneth.meyer@drake.edu]

Kory Schnoor Kory Schnoor has dedicated his professional career to the improvement of healthcare quality, safety, and efficiency through implementation of reform initiatives and information technology. Kory received a Master's Degree in Public Administration from Drake University (2011), and a Bachelor's Degree in Psychology from Iowa State University (2001). For many years, Kory held several direct service positions in social services agencies, focused on behavioral healthcare and community support services. In 2006, Kory joined the Iowa Department of Public Health to manage various statewide initiatives focused on traumatic brain injury, substance abuse treatment and recovery, and the Iowa e-Health project. Kory joined FEi Systems as a project manager in 2011, working with state governments to implement and manage behavioral health electronic health record (EHR) systems and IT solutions to improve the lives of individuals and families.

\section{REFERENCES}

GLAAD, Transgender Media and Education Campaign: http://www.glaad.org/transgender

Human Rights Campaign, Transgender Resources: http://www.hrc.org/topics/transgender

United States Office of Personnel Management, Guidance Regarding the Employment of Transgender Individuals in the Federal Workplace: http://www.opm.gov/policy-data-oversight/diversity-and-inclusion/referencematerials/gender-identity-guidance/http://transequality.org/resources/enda_by_the_numbers.pdf 


\section{APPENDIX}

\section{From Dan to Danita: LGBT Based Discrimination to Issues of Religious Freedom} Name:

\section{Case Log and Administrative Journal Entry}

This case analysis and learning assessment may be submitted for either instructor or peer assessment.

\section{Case Analysis:}

Major case concepts and theories identified:

What is the relevance of the concepts, theories, ideas and techniques presented in the case to that of public or private management?

Facts — what do we know for sure about the case? Please list.

Who is involved in the case (people, departments, agencies, units, etc.)? Were the problems of an "intra/interagency" nature? Be specific.

Are there any rules, laws, regulations or standard operating procedures identified in the case study that might limit decision-making? If so, what are they?

Are there any clues presented in the case as to the major actor's interests, needs, motivations and personalities? If so, please list them.

\section{Learning Assessment:}

What do the administrative theories presented in this case mean to you as an administrator or manager?

How can this learning be put to use outside the classroom? Are there any problems you envision during the implementation phase?

Several possible courses of action were identified during the class discussion. Which action was considered to be most practical by the group? Which was deemed most feasible? Based on your personal experience, did the group 
reach a conclusion that was desirable, feasible, and practical? Please explain why or why not.

Did the group reach a decision that would solve the problem on a short-term or long-term basis? Please explain.

What could you have done to receive more learning value from this case? 
NOTES 